\title{
The role of unsaturated zone in estimating groundwater recharge in arid and semiarid areas as depicted by geochemical tracers
}

\author{
Tianming Huang ${ }^{1,2, *}$, Baoqiang $\mathrm{Ma}^{1,3}$, Yin Long ${ }^{1,2}$, and Zhonghe Pang ${ }^{1,2}$ \\ ${ }^{1}$ Institute of Geology and Geophysics, Chinese Academy of Sciences, Beijing 100029, China \\ ${ }^{2}$ College of Earth Sciences, University of Chinese Academy of Sciences, Beijing 100049, China \\ ${ }^{3}$ College of Geoscience and Surveying Engineering, China University of Mining and Technology, \\ Beijing 100083, China
}

\begin{abstract}
In arid and semiarid area, the recharge rate is relatively limited and the unsaturated zone (UZ) is commonly thick. The moisture in the UZ may represent the water infiltrating from precipitation during the past decades to thousands of years. Therefore, the multiple geochemical tracers in soil moisture, including $\mathrm{Cl}$ (chloride mass balance), ${ }^{3} \mathrm{H}$ (tritium peak displacement), $\mathrm{NO}_{3},{ }^{2} \mathrm{H},{ }^{18} \mathrm{O}$, can be used to estimate diffuse recharge rate and related recharge characteristics. Based on $45 \mathrm{UZ}$ profiles with maximum depth of $62 \mathrm{~m}$ in the Ordos Basin in NW China, a typical arid and semiarid area, we has used multiple geochemical tracers to study the following recharge informations: (1) reconstruction of groundwater recharge history, (2) determination of groundwater recharge mechanism, and (3) assessment of impact of vegetation changes on groundwater recharge. The results show that the soil texture (epically the shallow soil), vegetation and precipitation mainly control the recharge rate. This study also found that shallow groundwater in arid and semiarid areas is often not in equilibrium with near-surface boundary conditions. To estimate present recharge information, the UZ must be considered. The whole recharge process from precipitation to groundwater cannot be well understood unless the UZ have been included in arid and semiarid areas.
\end{abstract}

\section{Introduction}

The unsaturated zone is an important link between groundwater and the land surface, and can provide storage capacity for both water and contaminants. Consequently, the solute profile of the unsaturated zone can provide many informations on groundwater recharge. However, the UZ is usually a neglected component, as hydrogeologists are primarily concerned with the aquifer (the saturated zone) and agriculturalists are concerned with the root zone (commonly less than $2 \mathrm{~m}$ ) [1]. In recent years, some studies have focused on the UZ to study groundwater recharge in arid and semiarid area, and also pollutant mobilization. In an arid and semiarid area, because the soil moisture infiltrates relatively

* Corresponding author: tmhuang@mail.iggcas.ac.cn 
slowly and the UZ is commonly thick in an arid area, the soil moistures recharged over the past decades to thousands of years remain in the UZ. Therefore, much information can be obtained from the soil solute profiles, e.g., (1) reconstruction of groundwater recharge history, (2) determination of groundwater recharge mechanism, and (3) assessment of impact of vegetation changes on groundwater recharge. The goal of this study is to demonstrate the role of geochemical tracers (such as water chemistry, ${ }^{3} \mathrm{H},{ }^{13} \mathrm{C},{ }^{14} \mathrm{C},{ }^{2} \mathrm{H}$ and ${ }^{18} \mathrm{O}$ ) in the groundwater recharge in arid and semiarid areas.

\section{Methodology}

\subsection{Terminology}

Ground water recharge includes recharge as a natural part of the hydrologic cycle and human-induced recharge. Natural recharge to the water table can be diffuse or localized. Diffuse recharge is the widespread movement of water from land surface to the water table as a result of precipitation over large areas infiltrating and percolating through the unsaturated zone [2]. The region of the unsaturated zone below the zero flux plane is called the vadose zone. Water percolating into the vadose zone is sometimes referred to as potential recharge since it is unlikely to be removed upward to the surface, and has to be distinguished from actual recharge which has reached the water table [3]. Potential recharge is labelled simply as (groundwater) recharge for brevity in this study, though it is recognized that the two are not equivalent.

\subsection{Methodology}

In arid and semi-arid areas, the most useful methods for estimating groundwater recharge are based on environmental tracer [4] and the two methods, i.e., Chloride Mass Balance (CMB) and the 1963's tritium peak displacement (TPD) under the one-dimensional piston flow are most reliable and successful [5, 6]. The CMB is based on the following assumptions: (1) the only source of $\mathrm{Cl}$ is atmospheric (rainfall and dry deposition), and there is no contribution of $\mathrm{Cl}$ from weathering; (2) the surface runoff is negligible; and (3) the 1-D vertical steady-state $\mathrm{Cl}$ flux is tenable such that the recharge rate $(R)$ can be obtained by $R=J / C s$, where $J$ is the atmospheric $C l$ deposition $(J=P \times C p+D$, where $P$ is precipitation, $C p$ is the $\mathrm{Cl}$ concentration in precipitation, and $D$ is the net dry deposition) and $C s$ is the $\mathrm{Cl}$ concentration of the soil moisture. The atmospheric $\mathrm{Cl}$ deposition can be obtained from the precipitation and the $\mathrm{Cl}$ content in the precipitation. The maximum value of tritium from precipitation has been reached in 1963, which can be preserved in the UZ if the 1963's moisture has not been reached the water table. Based on the depth of the peak position, the recharge rate can be estimated by $R=S \cdot \theta /(t-1963)$, where $S$ is the depth of the tritium peak, $\theta$ is the volumetric moisture content and $\mathrm{t}$ is the sampling time.

\subsection{The UZ profile}

Details on the formations that are present in the study area (the Ordos Basin), including the Northern Plateau and the Loess Plateau located northwards (Fig. 1) can be found in Hou and Zhang [7] for topography, geomorphology, climate, geological and hydrogeological conditions. In the past 10 years, 45 soil profiles have been drilled (Fig. 1) with a maximum depth of $62 \mathrm{~m}$. Measurements included moisture content, particle size, $\mathrm{Cl}$ and $\mathrm{NO}_{3}$. Meanwhile, groundwater chemistry, ${ }^{3} \mathrm{H},{ }^{13} \mathrm{C},{ }^{14} \mathrm{C}$ (measured by AMS), ${ }^{2} \mathrm{H}$ and ${ }^{18} \mathrm{O}$ have been also analysed. 


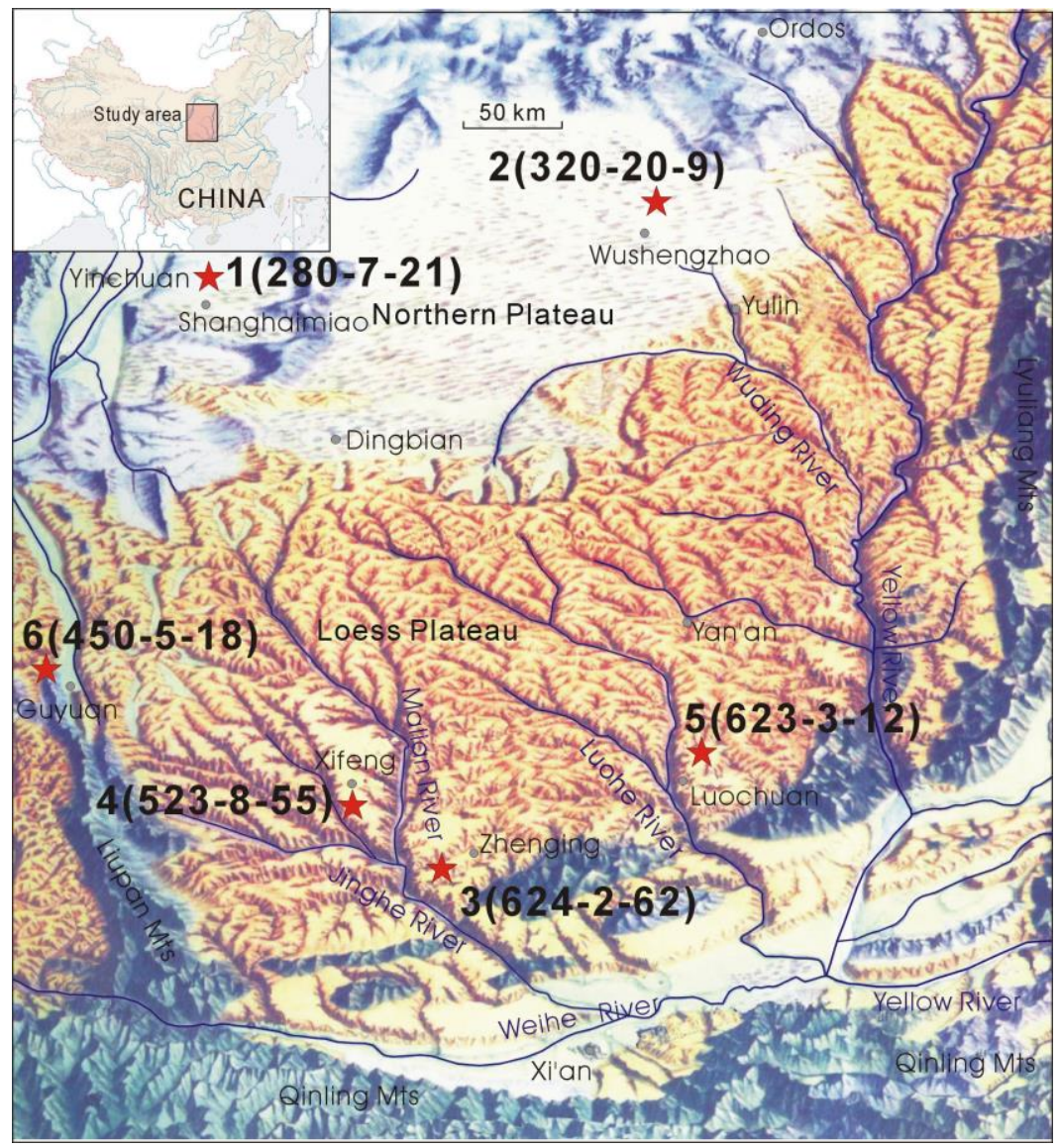

Fig. 1. The study areas in the Ordos Basin (red star). The number meaning: 3 (624-2-62): location (precipitation ( $\mathrm{mm} / \mathrm{yr}$ )-number of soil profile-the maximum depth of soil profile $(\mathrm{m})$. The base map is modified from Hou and Zhang [7].

\section{Applications of UZ}

\subsection{Recharge history}

The recharge history has been determined in the Shanghaimiao (location 1 in Fig. 1) using the soil chloride profiles and multiple tracers $\left({ }^{2} \mathrm{H},{ }^{18} \mathrm{O},{ }^{13} \mathrm{C},{ }^{14} \mathrm{C}\right.$ and water chemistry) of groundwater. The results show that the present diffuse recharge beneath the grassland is $0.11-0.32 \mathrm{~mm} / \mathrm{yr}$, based on the CMB from 7 soil profiles. The chloride accumulation age is approximately 2500 years at a depth of $13 \mathrm{~m}$ in the unsaturated zone. The average $\mathrm{Cl}$ content in soil moisture in the upper $13 \mathrm{~m}$ of the unsaturated zone ranges from $2842 \mathrm{mg} / \mathrm{L}$ to $7856 \mathrm{mg} / \mathrm{L}$, while the shallow groundwater $\mathrm{Cl}$ content ranges from $95 \mathrm{mg} / \mathrm{L}$ to $351 \mathrm{mg} / \mathrm{L}$. The corrected ${ }^{14} \mathrm{C}$ age of regional shallow groundwater around the location 1 ranges from 4327 to 29708 years (Fig. 2). The water stable isotopes $\left({ }^{2} \mathrm{H}\right.$ and $\left.{ }^{18} \mathrm{O}\right)$ show that the shallow groundwater is unrelated to modern precipitation [8]. The shallow groundwater was recharged during the cold and wet phases of the late Pleistocene and Holocene humid phase based on paleoclimate, and consequently, the groundwater resource is non-renewable. Due to the limited recharge rate and thick unsaturated zone, the present shallow groundwater has 
not been in hydraulic equilibrium with near-surface boundary conditions in the past 2500 years.

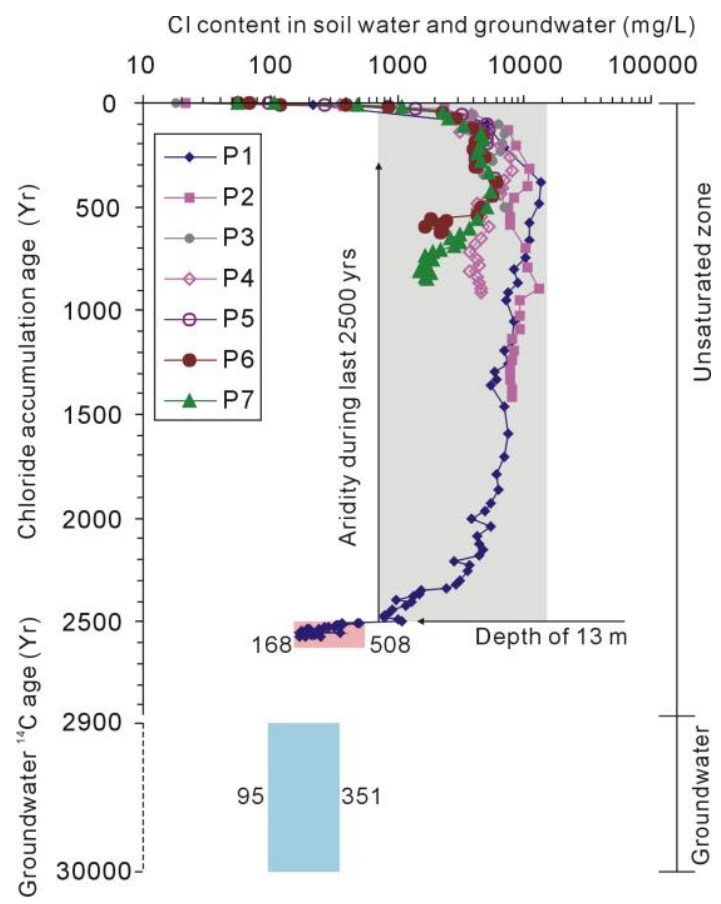

Fig. 2. Groundwater recharge history in the western part of the North Plateau (Location 1).

\subsection{Recharge mechanism}

The soil water infiltration mechanism (piston vs. preferential flow) is important to constrain the recharge processes and the solute movement. This study combined evaluations of the thick UZ with those of the saturated zone and used multiple tracers, such as $\mathrm{Cl}, \mathrm{NO}_{3}, \mathrm{Br}$, ${ }^{2} \mathrm{H},{ }^{18} \mathrm{O},{ }^{13} \mathrm{C},{ }^{3} \mathrm{H}$ and ${ }^{14} \mathrm{C}$, to study groundwater recharge characteristics in an integrated loess tableland in the Loess Plateau (Location 3, 4, 5), where precipitation infiltration is the only recharge source for shallow groundwater. The results indicate that diffuse recharge beneath crops, as the main land use of the Location 3, is 55-71 $\mathrm{mm} \mathrm{yr}^{-1}$ based on the CMB of soil profiles. The length of time required for annual precipitation to reach the water table is $160-400$ yrs. The groundwater is all pre-modern water and paleowater, with corrected ${ }^{14} \mathrm{C}$ age ranging from 136 to 23412 yrs [9]. The higher $\mathrm{Cl}$ and $\mathrm{NO}_{3}$ contents in the upper UZ compared to both in the deep UZ and shallow groundwater can be explained by recent human activities. The shallow groundwater has not been in hydraulic equilibrium with present near-surface boundary conditions. When preferential flow has been classically favoured for loess by most Chinese scientists, the homogeneous material of the UZ and relatively old groundwater age imply that piston flow is the dominant recharge mechanism for the shallow groundwater in the tableland.

\subsection{Impact of vegetation changes on groundwater recharge}

Changes in land use, particularly transitions between grasslands and forests, have potentially large impacts on water balance and salt fluxes in the ecosystem. This is mainly 
due to the differences in evapotranspiration for different vegetation and root systems. Following land-use change (e.g. tree planting) that results in a decrease of groundwater recharge, the only factor that changes is the increased evapotranspiration of the vegetation. As plants exclude chloride during evapotranspiration, increased evapotranspiration will result in increased chloride content in the soil profile [5]. Therefore, comparison of soil chloride profiles before and after land-use change is a useful tool to measure impacts on groundwater resources, especially in (semi)arid areas such as the Loess Plateau. The case study of a loess-terrace agriculture region in the Location $6[10,11]$ shows that the conversion from natural ecosystem to winter wheat 100 years ago has decreased groundwater recharge by $42-50 \%$ and that the conversion from winter wheat to alfalfa has decreased groundwater recharge to almost zero.

\section{Conclusions}

The UZ plays a key role in the evaluation of groundwater resource in arid and semi-arid areas. The related characteristics of groundwater recharge can be obtained by the use of tracers in UZ in the arid and semiarid areas, especially where the shallow groundwater has not been in hydraulic equilibrium with near - surface boundary conditions. The whole recharge process from precipitation to groundwater cannot be well understood unless the UZ have been included in arid and semiarid areas.

The work is supported by the National Natural Science Foundation of China (Grant 41672254) and the Youth Innovation Promotion Association CAS (2018087).

\section{References}

1. T. Huang, S. Yang, J. Liu, Z. Li, Geosci. J. 20, 495 (2016)

2. W.M. Alley, Groundwater in Encyclopedia of Inland Waters (2009)

3. J.B. Gates. Doctor Thesis, University of Oxford (2007)

4. G.B. Allison, G.W. Gee, S.W. Tyler, Soil Sci. Soc. Am. J. 58, 6 (1994)

5. B.R. Scanlon, K.E. Keese, A.L. Flint, Hydrol. Process. 20, 3335 (2006)

6. Z. Pang, T. Huang, S. Yang, L. Yuan, J. Eng. Geol. 26, 51 (2018)

7. G. Hou, M. Zhang, Groundwater resources and their sustainable utilization in the Ordos Basin. Shaanxi Science and Technology Press (2014)

8. T. Huang, Z. Pang, J. Liu, L. Yin, W.M. Edmunds, Hydrol. Process. 31, 1047 (2017)

9. T. Huang, Z. Pang, J. Liu, J. Ma, J. Gates, Hydrogeol. J. 25, 2049 (2017)

10. T. Huang, Z. Pang, Hydrogeol. J. 19, 177 (2011)

11. T. Huang, Z. Pang, W.M. Edmunds, Hydrol Process. 27, 1238 (2013) 